\title{
BUfFER ZONE MONITORING PLAN FOR THE DOS RIOS SUBDIVISION GUNNISON, COLORADO
}

February 1996

\section{DISCLAIMER}

This report was prepared as an account of work sponsored by an agency of the United States Government. Neither the United States Government nor any agency thereof, nor any of their employees, makes any warranty, express or implied, or assumes any legal liability or responsibility for the accuracy, completeness, or usefulness of any information, apparatus, product, or process disclosed, or represents that its use would not infringe privately owned rights. Reference herein to any specific commercial product, process, or service by trade name, trademark, manufacturer, or otherwise does not necessarily constitute or imply its endorsement, recommendation, or favoring by the United States Government or any agency thereof. The views and opinions of authors expressed herein do not necessarily state or reflect those of the United States Government or any agency thereof. 
This report has been reproduced from the best available copy. Available in paper copy and microfiche

Number of pages in this report: 18

DOE and DOE contractors can obtain copies of this report from:

Office of Scientific and Technical Information

P.O. Box 62

Oak Ridge, TN 37831

(615) 576-8401

This report is publicly available from:

National Technical Information Service

Department of Commerce

5285 Port Royal Road

Springfield, VA 22161

(703) 487-4650 
BUFFER ZONE MONITORING PLAN FOR THE DOS RIOS SUBDIVISION GUNNISON, COLORADO

\section{February 1996}

$$
\text { Prepared for }
$$

U.S. Department of Energy

Environmental Restoration Division UMTRA Project Team Albuquerque, New Mexico

Prepared by Jacobs Engineering Group Inc. Albuquerque, New Mexico 

TABLE OF CONTENTS

Section

Page

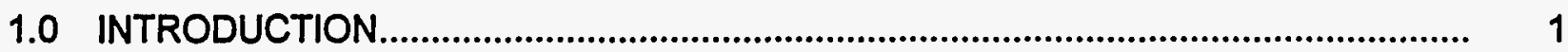

1.1 Purpose .............................................................................................................. 1

1.2 Background ............................................................................................................

1.3 Scope ......................................................................................................... 2

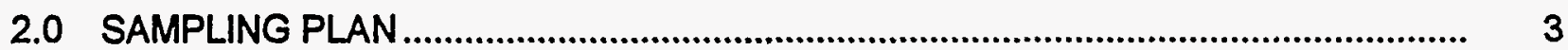

2.1 Sampling locations .................................................................................................. 3

2.2 Selection of analytes .............................................................................. 3

2.3 Sampling frequency...................................................................................................... 6

2.4 Interpretation of data ....................................................................................... 6

2.5 Data evaluation and action levels................................................................... 7

2.6 Data transmittal and confidentiality ................................................................ 7

2.7 Plan modifications and termination ................................................................... 8

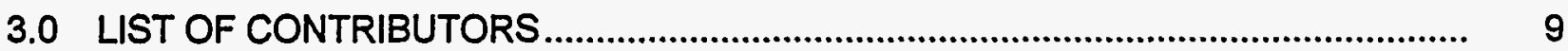

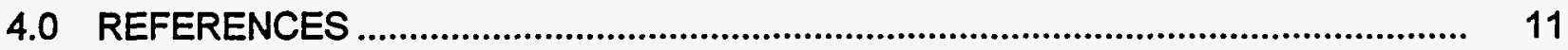




\section{LIST OF FIGURES}

Figure

Page

1 Private well sampling locations in the vicinity of the processing site, Gunnison, Colorado

\section{LIST OF TABLES}

Table

Page

1 Private well sampling locations downgradient from the Gunnison UMTRA processing site 


\section{LIST OF ACRONYMS}

Acronym

CDPHE

DOE

EPA

UMTRA

UMTRCA

WSAP

\section{Definition}

Colorado Department of Public Health and Environment

U.S. Department of Energy

U.S. Environmental Protection Agency

Uranium Mill Tailings Remedial Action

Uranium Mill Tailings Radiation Control Act

water sampling and analysis plan 


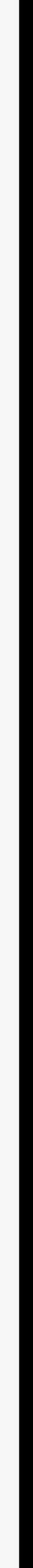




\subsection{INTRODUCTION}

\subsection{PURPOSE}

This report presents a plan for water quality monitoring at the Dos Rios subdivision (Units 2, 3, and the Island Unit) that is intended to satisfy the informational needs of residents who live southwest (downgradient) of the former Gunnison processing site. Water quality monitoring activities described in this report are designed to protect the public from residual contamination that entered the ground water as a result of previous uranium milling operations. Requirements presented in this monitoring plan are also included in the water sampling and analysis plan (WSAP) for the Gunnison Uranium Mill Tailings Remedial Action (UMTRA) Project site. The Gunnison WSAP is a site-specific document prepared by the U.S. Department of Energy (DOE) that provides background, guidance, and justification for future ground water sampling and analysis activities for the UMTRA Project Gunnison processing and disposal sites. The WSAP will be updated annually, as additional water quality data are collected and interpreted, to provide ongoing protection for public health and the environment.

\subsection{BACKGROUND}

The Gunnison uranium mill tailings site is just south of the city limits of Gunnison, Colorado. The entire site covers 61 acres (ac) (25 hectares [ha]) in the valley of the Gunnison River and Tomichi Creek. Contaminated materials at the Gunnison processing site include the tailings pile, covering about 35 ac (14 ha) to an average depth of 9 feet ( $\mathrm{ft}$ ) (3 meters [m]) and containing 459,000 cubic yards $\left(\mathrm{yd}^{3}\right)\left(351,000\right.$ cubic meters $\left.\left[\mathrm{m}^{3}\right]\right)$. Site characterization activities have been conducted at and in the vicinity of the Gunnison processing site since 1983. The results of these investigations indicate that uranium processing activities have affected the ground water quality at and downgradient of the Gunnison processing site and that uranium is the major hazardous constituent of concern.

The following corrective actions are being conducted pursuant to the requirements of the Uranium Mill Tailings Radiation Control Act (UMTRCA) (42 USC $\$ 7901$ et seq.) to satisfy the U.S. Environmental Protection Agency (EPA) standards (40 CFR Part 192) for cleanup, stabilization, and control of the residual radioactive materials:

- Tailings have been relocated to an engineered disposal cell approximately 6 miles (mi) (10 kilometers [km]) east of the town of Gunnison and $0.4 \mathrm{mi}$ $(0.6 \mathrm{~km})$ south of the Gunnison County landfill.

- Water quality is monitored at selected locations at and downgradient of the former Gunnison processing site in the Dos Rios subdivision (Units 2, 3, and 
the Island Unit). Water sampling locations are discussed in detail the WSAP (DOE, 1995).

A ground water restoration alternative will be selected and implemented for the area affected by previous uranium processing activities.

\subsection{SCOPE}

Water quality monitoring at Gunnison involves health-protection monitoring in the Dos Rios subdivision. Future ground water monitoring of private domestic wells is advisable in the Dos Rios subdivision for the following reasons:

- Although the DOE provides an alternate water supply system, a buffer zone of representative domestic wells in Unit 2 of the Dos Rios subdivision will be monitored. A water main was installed along Camino del Rio in Unit 2. However, hookup to the water distribution system is optional (at the residents' expense) for residents along Camino del Rio. As a result, some of these residents may be at risk if significantly contaminated ground water extends to this area.

- The water distribution system is connected to households for potable water consumption and washing. Water needed for irrigation and livestock may be drawn from private irrigation wells. Ground water from these irrigation wells should be monitored to provide assurance that the water quality remains suitable for irrigation and livestock watering.

In addition, the water quality data will provide valuable information on analytical concentration trends that will be useful during the ground water restoration phase of the UMTRA Project.

This buffer zone ground water monitoring plan is designed to be flexible and to take into account changes or trends in uranium concentrations in ground water. If significant changes in uranium concentrations are noted, the DOE and Colorado Department of Public Health and Environment (CDPHE) will review the water quality and hydrogeologic conditions and determine an appropriate course of action. Data interpretation is discussed in Section 2.4 of this document; action level criteria and plan modifications are discussed in Sections 2.5 and 2.7, respectively. 


\subsection{SAMPLING PLAN}

\section{$2.1 \quad$ SAMPLING LOCATIONS}

Previous characterization activities have indicated that elevated concentrations of uranium extend approximately $8100 \mathrm{ft}(2500 \mathrm{~m})$ to the southwest (downgradient) of the processing site and into portions of the Dos Rios subdivision (DOE, 1994). Uranium is used to define the extent of contamination because of its relative mobility in ground water. Elevated uranium concentrations pose a potential health risk to some areas in the Dos Rios subdivision. Private domestic wells in a buffer zone area (Unit 2) and an irrigation well within Unit 3 of the Dos Rios subdivision will be monitored.

Ground water will be sampled in the vicinity of the former Gunnison processing site, as specified in Table 1 and shown in Figure 1. The rationale for sampling selected private wells in the Dos Rios subdivision is discussed below.

Ground water samples will be collected from private wells that supply drinking water west of the Gunnison River (in the buffer zone). These wells are currently beyond the influence of the uranium plume, but will be monitored to ensure that uranium concentrations do not increase in the future.

Some residences have been connected to the alternate water supply but may be using their private wells for irrigation. As a result, water quality monitoring in a private irrigation well will ensure the water is within acceptable guidelines for the environment.

Table 1 describes recommended sampling locations and the rationale for sampling selected private wells. Figure 1 shows private well sampling locations. Unfiltered samples will be collected from the domestic wells.

\subsection{SELECTION OF ANALYTES}

The selection of analytes is based on information from the Gunnison baseline risk assessment (DOE, 1994), the remedial action plan (DOE, 1992), and historical data. Water quality samples will be collected semiannually from all the locations referred to in Table 1, with the exception of well GUN-01-0468, and will be analyzed for the following constituents: uranium, alkalinity, dissolved oxygen, oxidation/reduction potential, $\mathrm{pH}$, specific conductivity, and temperature.

Well GUN-01-0468 will be sampled in the fall for the constituents listed above and will be sampled in the spring for the constituents listed above plus the following additional constituents: arsenic, cadmium, calcium, chloride, cobalt, gross alpha, iron, lead-210, magnesium, manganese, polonium-210, potassium, radium-226 and -228 , sodium, sulfate, total dissolved solids, and thorium-230. 
Table 1. Private well sampling locations downgradient from the Gunnison UMTRA processing site

\begin{tabular}{|c|c|c|}
\hline Well ID & Description & Sampling rationale \\
\hline $\begin{array}{l}\text { GUN-01-0468 } \\
\text { GUN-01-0600 }\end{array}$ & $\begin{array}{l}\text { Domestic irrigation wells adversely } \\
\text { affected by the uranium plume }\end{array}$ & $\begin{array}{l}\text { Ensures safety of these wells continues for irrigation and } \\
\text { livestock uses. }\end{array}$ \\
\hline $\begin{array}{l}\text { GUN-01-0469 } \\
\text { GUN-01-0665 } \\
\text { GUN-01-0667 } \\
\text { GUN-01-0680 } \\
\text { GUN-01-0683 } \\
\text { GUN-01-0685 }\end{array}$ & $\begin{array}{l}\text { Domestic buffer zone wells in Unit } \\
2 \text { of the Dos Rios subdivision, not } \\
\text { currently affected by the uranium } \\
\text { plume. Residents have the option } \\
\text { to hook up to the water distribution } \\
\text { system. }\end{array}$ & $\begin{array}{l}\text { The DOE is committed to monitoring a buffer zone of } \\
\text { domestic wells to ensure that the characteristics of the } \\
\text { uranium plume do not change and adversely affect wells in } \\
\text { this area. }\end{array}$ \\
\hline $\begin{array}{l}\text { GUN-01-0660 } \\
\text { GUN-01-0661 } \\
\text { GUN-01-0679 } \\
\text { GUN-01-0684 } \\
\text { GUN-01-0686 } \\
\text { GUN-01-0687 }\end{array}$ & $\begin{array}{l}\text { Alternate domestic wells in Unit } 2 \\
\text { of the Dos Rios subdivision, not } \\
\text { currently affected by the uranium } \\
\text { plume. Residents have the option } \\
\text { to hook up to the water distribution } \\
\text { system. }\end{array}$ & $\begin{array}{l}\text { One (or more) of these alternate wells will be sampled only } \\
\text { if one (or more) of the primary six buffer zone residents } \\
\text { (listed in the row above) is not home. Alternate sampling } \\
\text { locations were selected so that six buffer zone wells will be } \\
\text { monitored semiannually and so the geographic distribution } \\
\text { of buffer zone sampling locations is consistent with that of } \\
\text { the primary buffer zone locations (i.e., if a primary location } \\
\text { isn't accessible, a neighboring location will be sampled as } \\
\text { an alternate). }\end{array}$ \\
\hline
\end{tabular}

${ }^{\mathrm{a}}$ This well will be sampled if the well is accessible. 


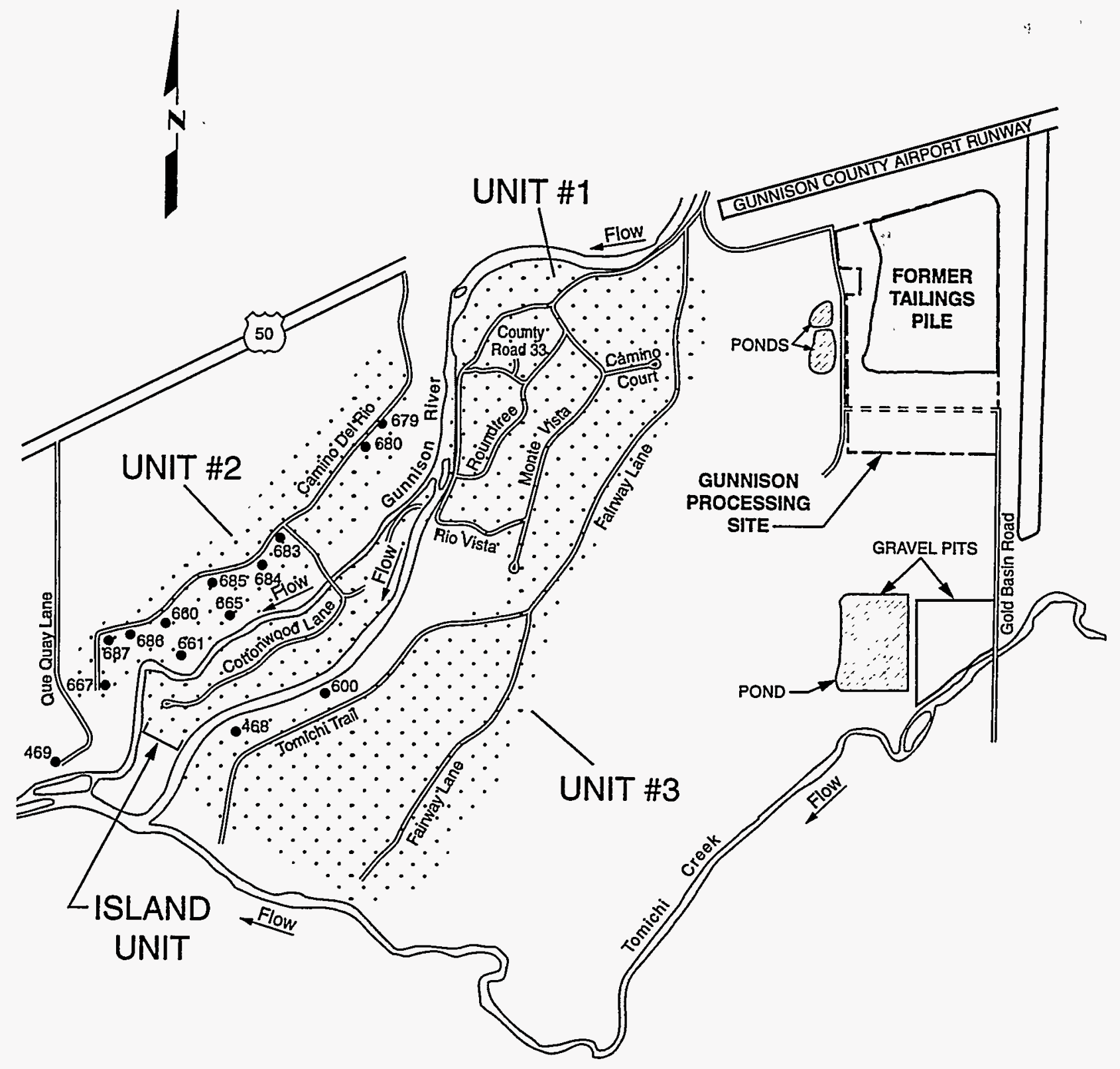

\section{LEGEND}

PRIVATE WELL
(APPROXIMATE LOCATION)

.. AREA WITHIN THE

-. DOS RIOS SUBDIVISION

(50) U.S. HIGHWAY

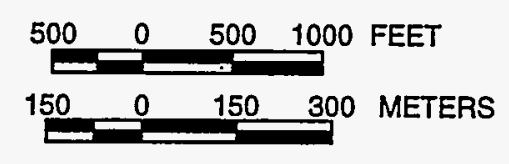

FIGURE 1

PRIVATE WELL SAMPLING LOCATIONS IN THE VICINITY OF THE PROCESSING SITE GUNNISON, COLORADO 
Laboratory analyses for parameters other than uranium are not necessary because the DOE monitor wells provide sufficient coverage to monitor water quality trends, as outlined in the WSAP. If there is a notable change in water quality in either well GUN-01-0468 or in the DOE monitor well clusters, analyses for additional parameters in the domestic irrigation wells and buffer zone wells will be considered.

\subsection{SAMPLING FREQUENCY}

Sampling is currently conducted semiannually. The sampling frequency after surface remedial action and during ground water restoration will be dependent upon future site characterization efforts and the ground water restoration alternatives selected. Sampling frequency and duration will be based on contaminant transport travel times and will account for a time lag following completion of surface remedial action. Based on the current hydrogeologic information available for the former processing site vicinity, the linear ground water velocity ranges from 56 to $1700 \mathrm{ft}$ per year $11.1 \times 10^{-4}$ to $33 \times 10^{-4}$ centimeters [cm] per second) and averages $270 \mathrm{ft}$ per year $\left(2.6 \times 10^{-4} \mathrm{~cm}\right.$ per second). The travel time estimate for contaminant movement will be further refined during the ground water restoration phase of the UMTRA Project, as additional data are acquired for velocity and dispersion calculations.

The ground water monitoring program and the sampling schedule ensure protection of human health and the environment. Variations in historical background water quality measurements, the geochemistry of the source term (tailings pore fluid solution), the ground water flow rate, and the possibility of seasonal variations in ground water quality are considered when the sampling frequency is established.

\section{$2.4 \quad$ INTERPRETATION OF DATA}

Long-term sampling frequencies and constituents will be determined, based on the following factors:

- Trends in uranium concentrations over time-Was an elevation in concentration a one-time occurrence or part of a statistical trend?

- Spatial changes in uranium concentrations-Does the plume appear to be spreading?

- Source term behavior-Do the mineralogy of subsurface soils, solubility of the hazardous constituents of concern, and ground water velocity suggest that source term concentrations are likely to increase or decrease with time?

Water quality and water level data will be reviewed during the data validation process. These results are sent to CDPHE as the validated data become 
available. The validated data will be evaluated for notable trends and variations in plume movement and water quality. Seasonal fluctuations will be taken into account in trend evaluations. Any deviations from the conceptual model of the hydrogeological and geochemical environment at and in the vicinity of the Gunnison processing site will be analyzed for significance.

\subsection{DATA EVALUATION AND ACTION LEVELS}

If a notable increase is detected in a contaminant concentration, several activities will be conducted to determine whether the increase indicates a significant change in water quality. Activities to determine the nature and extent of an increase in concentration may include reanalysis, resampling, comparison to other geochemical parameters, and trend analysis. Increases in analyte concentrations can occur for various reasons, including 1 ) artifacts in the process of sample collection and in laboratory analysis procedures, 2) changes in background water quality, 3) environmental changes that are unrelated to uranium processing activities, 4) a single localized pulse in the geochemical environment, or 5) an actual increase in concentration due to the previous uranium processing activities. If a significant increase is perceived to be a health threat, CDPHE and DOE will consult to evaluate potential actions.

The DOE will immediately notify CDPHE if the uranium concentration of any well in the buffer zone (Dos Rios subdivision, Unit 2) exceeds 0.020 milligrams per liter $(\mathrm{mg} / \mathrm{L})$ and if the uranium concentration in any irrigation well exceeds 0.200 $\mathrm{mg} / \mathrm{L}$. After notification to CDPHE, the contaminant levels and distribution will be evaluated as discussed in Section 2.7. Potential actions will then be determined. As an interim measure to a permanent long-term solution, bottled water may be supplied.

\subsection{DATA TRANSMITTAL AND CONFIDENTIALITY}

The DOE will provide CDPHE with the validated ground water sampling results and a data summary as soon as it is available. The format for the data summary sent to the CDPHE will be as follows:

Technical Assistance Contractor Site Hydrologist/Geochemist/Toxicologist Summary

1. Was the maximum concentration limit for any parameter exceeded in a domestic supply sample?

2. Did uranium concentrations from any domestic well located in the buffer zone exceed the background value of $0.0085 \mathrm{mg} / \mathrm{L}$ ?

3. Did the uranium concentration from a buffer zone well exceed $0.020 \mathrm{mg} / \mathrm{L}$ ? 
4. Did the uranium concentration from a private irrigation well exceed $0.20 \mathrm{mg} / \mathrm{L}$ ?

5. Were there any exceedances recorded in point-of-compliance monitor wells?

6. Were applicable surface water and sediment sample guidelines for any parameter exceeded?

7. Was new or increased contamination observed at any location that would indicate movement of the contaminant plume?

All buffer zone and irrigation well data will be treated as confidential by all parties; these data will be summarized in public documents by well number only, in accordance and agreement with the record sharing Memorandum of Understanding between the DOE and CDPHE.

\subsection{PLAN MODIFICATIONS AND TERMINATION}

Water quality monitoring data will be reviewed annually and the WSAP will be updated and revised as necessary. Plan modifications will be subject to review by the DOE and CDPHE.

Ground water monitoring shall not continue after the ground water is determined to be in compliance with the ground water cleanup standards promulgated under UMTRCA. Ground water monitoring in the Dos Rios subdivision will be terminated in consultation with CDPHE. 


\subsection{LIST OF CONTRIBUTORS}

The following individuals contributed to the preparation of this report.

\begin{tabular}{ll}
\hline Name & Contribution \\
\hline R. Dotson & Hydrology \\
J. Torline & Technical editing \\
L. Sanchez & Word processing \\
\hline
\end{tabular}





\subsection{REFERENCES}

DOE (U.S. Department of Energy), 1995. UMTRA Project Water Sampling and Analysis Plan, Gunnison, Colorado, DOE/AL/62350-132, Rev. 2, prepared for the U.S. Department of Energy, Environmental Restoration Division, UMTRA Project Team, Albuquerque, New Mexico.

DOE (U.S. Department of Energy), 1994. Baseline Risk Assessment of Ground water Contamination at the Uranium Mill Tailings Site Near Gunnison, Colorado, Rev. 1, prepared for the U.S. Department of Energy, UMTRA Project Office, Albuquerque Operations Office, Albuquerque, New Mexico.

DOE (U.S. Department of Energy), 1992. Remedial Action Plan and Site Design for Stabilization of the Inactive Uranium Mill Tailings Site at Gunnison, Colorado, prepared for the U.S. Department of Energy, UMTRA Project Office, Albuquerque Operations Office, Albuquerque, New Mexico.

\section{CODE OF FEDERAL REGULATIONS}

40 CFR Part 192, Health and Environmental Protection Standards for Uranium and Thorium Mill Tailings, U.S. Environmental Protection Agency.

\section{UNITED STATES CODE}

42 USC $\$ 7901$ et seq., Uranium Mill Tailings Radiation Control Act, 8 November 1978. 
